\title{
Autorské čtení: akční výzkum v pedagogické realitě Josef Nota
}

\begin{abstract}
Abstrakt:
Článek narativním zpưsobem představuje pozadí událostí, které vedly k zařazení disciplíny autorské čtení do výuky konkrétní základní školy. Výchozím předpokladem je, že autorské čtení může být vedle nácviku slohových útvarů vhodnou alternativou pro rozvíjení klíčových kompetencí. Hlavním cílem je ze získaných dat zformulovat vlastní pedagogické zkušenosti, které škola s autorským čtením za dobu osmileté praxe učinila. Sekundárním cílem je za pomoci případových studií ilustrovat způsoby, jak konkrétní žáci (i rodiče) mohou k autorskému čtení přistupovat.
\end{abstract}

Klíčová slova: Narativní výzkum, pedagogika, autorství, osobnost, autorské čtení, dialog, škola

\section{Výzkum experimentální dramatiky a autorského čtení}

Autorské čtení vzniklo jako psychosomatická disciplína určená pro možnost osobnostního rozvoje posluchačů DAMU v Praze (spolu s integrující disciplínou dialogické jednání s vnitřním partnerem). V oblasti pedagogické prrípravy budoucích učitelů se o specifickém prrínosu psychosomatických disciplín ve svých pracích zmiňují např. V. Švec, S. Suda a M. Matějíčková. ${ }^{1}$

V letech 2005-2018 byla disciplína autorské čtení součástí osobnostní výchovy oboru učitelství pro národní školu na Katedře pedagogiky a psychologie Pedagogické fakulty Jihočeské univerzity v Českých Budějovicích. Aktuálně je s dalšími předměty základem osobnostní výchovy oboru pedagogika volného času na Katedře pedagogiky Teologické fakulty Jihočeské univerzity v Českých Budějovicích. Data z výzkumu jsou průběžně publikována. ${ }^{2}$

Základními metodologickými východisky pro zkoumání autorského čtení je systematický, longitudinální výzkum tzv. experimentální dramatiky. Studium experimentální dramatiky vychází z předpokladu, že osobnost lze rozvíjet v dramatických herních situacích, které vyžadují (stejně jako situace pedagogické) uvědomělé, tvořivé, reflektované jednání v situaci „ted’a tady“. Při sběru dat se osvědčily postupy kvalitativní metodologie. Jde zejména o postupné zapisování prŕiběhu o nazírání na fenomény v experimentální dramatické situaci i mimo ni. K dispozici jsou prozatím příběhy, které jsou podloženy desítkami několikaletých případových studií, stovkami odborných

1 Srov. Milena MATĚJÍČKOVÁ, Josef NOTA, Stanislav SUDA, Observing Qualitative Changes in Psychosomatic Condition, The New Educational Rewiew 2/2011, s. 147-161.

2 Srov. Josef NOTA, Stanislav SUDA, Hledání společných znaků reflexí dialogického jednání, in: Podpora zdravého psychického vývoje $z$ aspektu ditěte a učitele, ed. Jiří JOŠT - František MAN - Alena NOHAVOVÁ, Praha: Eduko, 2013. 
kazuistik a tisíci psaných sebereflexí. ${ }^{3}$ Jádrem narativního přístupu je zaměření na dílčí, osobní, jedinečnou, osobní zkušenost participanta. Význam je generován tak, že participant propojuje různé aspekty svého života do podoby príiběhu. ${ }^{4}$

\section{Výzkumný problém a výzkumné otázky}

Záměr vznikl na základě aktuální situace školní praxe. Autorské čtení v prostř̌edí málotřídní školy prozatím nebylo zkoumáno: cílem tohoto článku je tedy reflexe pedagogické zkušenosti s autorským čtením $\mathrm{v}$ prostředí 1 . stupně ZŠ.

S ohledem na cíl studie je hlavní otázkou: Jaká je dosavadní pedagogická zkušenost s disciplínou autorské čtení $v$ prostředí málotřídní školy?

V souladu s běžnou praxí kvalitativního výzkumu ${ }^{5}$ je zformulovanou sekundární otázkou: Jakým způsobem budou konkrétní žáci (i rodiče) k autorskému čtení pristupovat?

\section{Design a metoda výzkumu}

Vstup do výzkumu je veden snahou získat integrovaný pohled na kontextovou logiku. Hlavní výzkumné otázce odpovídá kvalitativní prrístup, nebot v položené otázce je usilováno o získání hloubkového vhledu popisem př́padů, rozkrytí některých ne zcela jasných jevů. ${ }^{6}$

Přístup je opřen o postupy: 1) akčního výzkumu, nebot jsou témata vztažena k pedagogické praxi, proces výzkumu je procesem učení a změny, navíc výzkum s praxí jde ruku v ruce; 2) narativního zkoumání: jedná se o způsob dotazování explorujícího problém jedince. Narativní zkoumání se stalo nedílnou součástí kvalitativního výzkumu. Výzkumník přitom buduje komplexní, holistický obraz, analyzuje slova i rozsáhlejší verbální i neverbální významové jednotky, zachycuje podrobné názory informantů a provádí studii v přirozených podmínkách. Čermák upozorňuje, že zatímco výzkumník při tomto typu výzkumu ztrácí expertní postavení, validitu, reprezentativnost, jednoduchost, objektivitu, determinismus apod., získává oproti tomu komplexnost, heterarchii, indeterminismus a další. Výzkum bude navíc obohacen o možnost sdílení, participativně-dialogickou interpretaci a důvěryhodnost zjištění. Narativní modus je založen na přesvědčivé reprezentaci životní zkušenosti. ${ }^{8}$ Za výzkumnou strategii byl vybrán také specifický typ př́padové studie, nebot se výzkum týká situací, ve kterých si klademe otázky „JAK“ a „PROČ“ se dějí určité jevy, nad kterými máme jen omezenou kontrolu. ${ }^{9}$ Jedná se o určité unikátní prrípady, které byly vybrány záměrně, aby reprezentovaly: a) vztah žáků k disciplíně autorské čtení; b) umožnily reflektovat konkrétní způsob pedagogické intervence. Postup při sběru bylo nutné několikrát revidovat (u případových studií konkrétních žákủ bylo třeba ověřit platnost dat z pozorování pomocí dalších dat, např̀. získat výpovědi od rodičủ žáků.)

Nevýhodou bylo, že data z př́padových studií bylo nutné (kvưli rozsáhlosti) pro potřeby tohoto článku zestručnit, což vzniklému obrazu ubírá na komplexnosti.

3 Srov. Stanislav SUDA, Experimentální dramatika, České Budějovice: Nakladatelství Jihočeské univerzity v Českých Budějovicích, 2017, s. 227-238.

4 Srov. Ivo ČERMÁK, Myslet narativně (kvalitativní výzkum „on the road“), in: Kvalitativní výzkum ve vědách o člověku na prahu třetího tisíciletí, ed. Ivo ČERMÁK - Michal MIOVSKÝ, Brno: Psychologický ústav, 2002, s. 19-25.

5 Srov. Roman ŠVAŘíČEK, Klára ŠEĎOVÁ, Kvalitativní výzkum v pedagogických vědách: Pravidla hry, Praha: Portál, 2007.

6 Tamtéž, s. 69-71.

Srov. ČERMÁK, Myslet..., s. 11-25.

Tamtéž, s. 16.

SVAŘÍČEK, ŠEDOVÁ, Kvalitativní..., s. 105. 
Jména dětí byla změněna, aby byla zachována etická stránka výzkumu. Průběh výzkumu se řídil podmínkami terénu a byl v základu participativní.

\section{Data z výzkumu}

Základem dat je narativní interview, zúčastněné pozorování (zejména terénní poznámky a pedagogický deník), nestrukturované rozhovory se žáky a s jejich rodiči, hromadné diskuze s žáky, obsahová analýza autorských textů a nestrukturované, hloubkové rozhovory s pedagogy školy (ředitel školy, 2 pedagožky) a př́padové studie.

\section{Otázky kvality a interpretace výzkumu}

Triangulace byla použita nikoliv v kontextu snah o posílení validity sebraných dat (postavením dvou rozdílných metod proti sobě), ale ve druhém pojetí, tedy jako strategie k podpoře poznatků získáním dalších informací. ${ }^{10} \mathrm{~K}$ podpoře poznatků bylo využito zúčastněné pozorování, narativní interview a interpretace získaných dat od kolegů. ${ }^{11}$

\section{Začátek př́iběhu}

Málotřídní vesnická škola v jižních Čechách, ve které jsem pedagogem, má v současné době 35 dětí, 4 pedagogy na stálý pracovní poměr, díky rozsáhlé přestavbě 4 třídy a od roku 2020 je součástí budovy také mateřská škola. Avšak když jsem do ní nastoupil v roce 2010, situace byla poněkud odlišná: školu v té době navštěvovalo 12 dětí, měla 1 třídu a 2 pedagogické pracovníky (ředitele školy, který nastoupil rok přede mnou, a mne). Výchozí podmínky k mé první skutečné pedagogické praxi byly dramatické. Zmíněná (tehdy ještě) jednotřídní škola 1. stupně měla zoufalý nedostatek dětí (i místní obyvatelé posílali své děti raději do jiných škol v okolí), pověst školy byla v žalostném stavu a její Školní vzdělávací program byl formálně opsaný od jiné školy. Naší vstupní situaci popsal ředitel školy takto: „Sám jsem byl v této škole jen krátce, bojovali jsme proti zavření. Začínali jsme s malým počtem dětí. Vưbec jsme nevěděli, co pedagogicky děláme, ale dělali jsme, co nejvíce jsme mohli (ne uměli). Ohromně nám tehdy pomohlo, že naši školu objevili rodiče, kteři chtěli pro své děti nějakou alternativu v okolí, která by byla zdarma. A tou bylo málotřídní vzdělávání s možností nám do toho trochu mluvit. Prostě s fungující školskou radou. To, že máme nějakou prestiž, nám řekla až s velkým odstupem školní inspekce, do té doby jsem si myslel, že jenom diskutujeme s rodiči o jejich představách o vzdělávání (které byly totožné is mými). Pozitivním hodnocením od školní inspekce mi došlo, že náš pedagogický postoj má zastání v českém školním systému.

Př́chodem nových dětí z okolí jsme začali pedagogicky růst. Zvláště ty bystřejší děti nás inspirovaly $v$ utváření základních pedagogických postojü. Šlo o to, že jsme jim dali prostor $k$ učení a možnost podpory. Poté bylo zajímavé sledovat, jak látku zvládají bez nás, a odhadnout, kde je jim zapotřebí pomoci, ovšem jen tak, aby se do jejich činnosti nezasahovalo násilím, naprr. podle tematických plánů, které nejsou v pedagogickém procesu úplně zavazující (je to jen klíčová osnova pro učitele, aby se on sám $v$ pedagogické intervenci neztratil a orientoval se). Pro nás bylo naprosto zásadní sledovat, jak originálním, individuálním způsobem se konkrétní dítě bliží k očekávaným výstupům

10 Tamtéž, s. 203

11 Srov. Michal MIOVSKÝ, Kvalitativní prístup a metody v psychologickém výzkumu, Praha: Grada, 2006. 
v 5. ročníku. Naší zásadou pedagogické intervence se stal individuální přístup ve smyslu: rozvíjet celého člověka, $v$ oblasti školních výsledkư ty slabši žáky podporovat a chránit před opakovaným zaživíním neúspěchu, talentované hlavně nikým a ničím nebrzdit. Ideou se stalo a zủstává štastné dítè. Pro školu se staly zásadní otázky směřující $k$ tomu, jak udělat žáka ve školním prostředí kompetentního do té míry, že nás pedagogy bude potřebovat čím dál tím méně v př́mé intervenci (k výkladu, přikazování, poučování). Že budeme spolu spiše nacházet dialog."

Při nestrukturovaných rozhovorech s ředitelem školy jsem si uvědomil, že v době pedagogických začátků jsme zřejmě poprvé okusili maximální pedagogickou svobodu i z toho plynoucí odpovědnost za důsledky pedagogických intervencí. Jen zmíním, že naprostá většina tehdejších žáků měla zpočátku téměř nulovou motivaci ke školní práci, někteři z nich navíc i snížené studijní předpoklady. Výchozí nehostinné podmínky se ukázaly jako velmi výhodné a mě s kolegou podnítily k bleskovému formulování základních idejí, které se do budoucna staly i kostrou formálních dokumentů (̌̌VP).

Když jsem při nástupu do zmiňované školy v rámci úvazku dostal na starost (kromě dalších předmětů) i vedení „slohové výchovy“ u žáků 3., 4. a 5. ročníku (7 dětí), zkusil jsem v rámci vznikajících pedagogických idejí experiment s autorským čtením.

\section{Problematika slohových prací}

Při vstupu do praxe jsem se slohovou a komunikační výchovou žádnou reálnou pedagogickou zkušenost neměl, jen mlhavé tušení, že v RVP existuje vzdělávací oblast pojmenovaná „jazyk a jazyková komunikace“: cílem v této oblasti je, aby žák získal znalosti a dovednosti použitelné v praktických životních situacích (stal se jazykově kompetentním) - mluvnicky i písemně.

Při pročíání běžných metodik $\mathrm{v}$ učebnicích pro 1 . stupeň jsem zjistil, že v mluveném i psaném projevu je důraz kladen spiše na zvládnutí základních slohových útvarů („vypravování“ a „popis“) než na rozvíjení zmíněných kompetencí. V metodických materiálech jde - zjednodušeně řečeno - prvotně o nácvik: nejprve si žák osvojí základní jazykové prostředky pro práci s osnovou a reprodukuje jednoduché texty. To, co je nazýváno „slohovým cvičením“, je v učebních textech spiše okrajová záležitost. Jejich realizace (nácvik) bývá většinou od 2. ročníku, a to právě prostřednictvím „slohových cvičeni“ (slohová cvičení se dále různě dělí dle metodického cíle, např̀. na invenční, kompoziční, stylizační...).

Na 1. stupni se žáci nejčastěji setkávají s tzv. doplňovacími cvičeními, pro příklad: „Jaká byla Sněhurka? Vyber vhodná slova z nabídky a popis poté napiš (...) Sněhurka byla krásná jako... Vlasy měla černé jako... Plet̉ měla hebkou jako... Její oči byly... a ústa jako... Nabídka slov: hedvábí, víla, havran, uhel ..." ${ }^{12}$.

V učebních textech staršího data vydání jsou slohová cvičení realizována různými „obměňovacími“ typy př́kladi̊, např. převést text do času minulého. V současných metodických textech se již „obměňovací príklady neobjevují tak často, nebot jejich přínos pro kultivaci jazykových dovedností bývá - přinejmenším - sporný.

Můžeme zmínit i cvičení substituční: „Nahrad’ v textu tato slova synonymy: vkládají se, otáćí se, odstraní se, bledne, třeba, slouži “13 či tzv. cvičení modelová, tedy vysloveně dle nápodoby: „Podle vzorců utvoř cvičení o zimě: $\mathrm{V} 1$, ale $\mathrm{V} 2, \mathrm{~V} 1$, protože $\mathrm{V} 2, \mathrm{~V} 1$, protože $\mathrm{V} 2$ a V3“14.

12 Eva HOŠNOVÁ, Český jazyk pro 2. ročník Ž̌s, Praha: SPN, 2006, s. 82.

13 Jaroslava KOSOVÁ, Český jazyk - učebnice pro 3. ročník základní školy, Plzeň: Fraus, 2009, s. 50.

14 Tamtéž, s. 75. 
Na konci této metodické cesty (od 4. ročníku ZŠ) se tradičně probírají „stylizační cvičeni“. Tato cvičení autoři materiálů definují jako prostor pro vlastní invenci žáků, nebot žák má možnost pracovat samostatně při tvorbě nejen vět, ale i celků. S úkolem je spojena tvorba osnovy, zařazování přímé řeči a respektování pravidel slohového útvaru, který se právě probírá. Osobně se domnívám, že určený prostor pro onu žákovskou invenci je poněkud přeceňován, nebot slohová stylizační cvičení jsou opět těsně spjata s nácvikem formálních slohotvorných náležitostí, například:

1) Které větné celky byste označili za úvod?

2) Které větné celky pokládáte za závěr?

3) Jak byste nazvali to, co je mezi úvodem a závěrem?

4) Dokážete tuto část ještě více rozčlenit?

5) Sestavte osnovu celého vyprávění.

6) Všimněte si v textu vět, za kterými jsou napsány vykřičníky - věty zvolací. Vyhledejte prríklady takových vět a přečtěte je se správnou melodií. ${ }^{15}$

Na středních školách je poté zpravidla sledován stejný cíl: vyškolit studenta ve funkční stylistice, tedy ve tvorbě slohových útvarů (popis, výklad, úvaha, zpráva). Předpokládá se (někdy mylně), že student ovládá odpovídající slohové postupy i v praxi - tedy při psaní textů. ${ }^{16}$

Obecně: jakýkoliv nácvik rozvíjí vývojově nižší osobnostní struktury jedince než postupy vyžadující vlastní tvorbu, představivost a divergentní myšlení. Ovšem zmíněná metodická struktura nejenže může myšlení omezovat, ale zároveň poskytuje i bezpečí, zvláště u mladších žáků. Řídit se strukturovanou metodikou zmiňovaných učebnic je tedy bezpečné pro žáka i učitele, nebot žák tuší, co se po něm chce, a učitel nemá starost s tím, co po žácích chtít. Cíle k hodnocení má navíc $\mathrm{v}$ učebnicové předloze.

Stálo by ovšem za nějaký relevantní výzkum vysledovat, jaké mají pedagogové implicitní pojetí slohové výuky a co je pro učitele v textech tou tušenou „vyšší kvalitou“. Žák je totiž cvičen ve funkčním psaní a metodicky dostává „slohové nástroje“. Ve své podstatě předem (a někdy právem) předjímáme, že žák nemá (a zpočátku ani přiliš nemůže mít) estetický cit. Ale „slohovku“by měl umět napsat každý. Nácvik proto spočívá v osvojení základních orientačních bodů, kterými se jedinec při psaní od počátku řídí. Jelikož se tyto orientační body týkají struktury psaní, tato struktura vede i myšlení (hovoří se o konvergentním způsobu řešení problémů). Proto možná není úplně namístě se rozčilovat, když skupina žáků - nezávisle na sobě - napíše velmi podobnou práci. Dochází tak k jevu, který učitelé na 1 . stupni velmi dobře znají (češtináři př̀i opravování maturitních prací nepochybně také).

Je vcelku možné, že se žák nácvikem slohotvorných cvičení autorsky „najde“ a skrz tato cvičení originalita, osobitost a invence jaksi mimochodem probleskne. Do osvojených postupů žák může (měl by) „zasadit“ něco vlastního. Stane se autorem. Autorství může být onou kvalitou a prototypy „slohovek“ ze tříd zmizí. Domnívám se, že potencionální kritika přístupu si žádá obezřetnost: žrejmě nezáleží pouze na metodice, ale také na způsobu, jakým učitel s metodikou pracuje. Pro rozvoj tvořivosti je pak zásadní, kolik prostoru pro vlastní invenci učitel dovolí žákům, kteří mají potencionál k vlastní tvorbě. ${ }^{17}$

V ŠVP naší školy je vzdělávací obor český jazyk a literatura součástí vzdělávací oblasti „jazyk

15 Rudolf ČECHURA, Hana STAUDKOVÁ, Miroslava HORÁČKOVÁ, Český jazyk pro 4. ročník, Praha: Alter, 1996, s. 15.

16 Srov. Zbyněk FIŠER, Tvưrčí psaní, Brno: Paido, 2001, s. 29.

17 Srov. Josef NOTA, Experimentální dramatika: Autorské čtení u žáků na 1. stupni, in: Perspektivy výchovy a vzdělávání v podmínkách současného světa, ed. Miriam PROKEŠOVÁ, Ostrava: ČPDS, 2017, s. 89-94. 
a jazyková komunikace“. Obsah vzdělávacího oboru český jazyk a literatura má komplexní charakter, ale pro přehlednost je rozdělen do tř́ složek: komunikační a slohová výchova, jazyková výchova a literární výchova. Ve výuce se však vzdělávací obsah jednotlivých složek vzájemně prolíná. Při tvorbě ŠVP byly základem (mimo jiných) i tyto výchovné a vzdělávací strategie směřující k rozvíjení klíčových kompetencí:

- samostatnost, organizace vlastní činnosti;

- vlastní úsudek, iniciativa, tvořivost, zodpovědnost;

- komunikační dovednosti, spolupráce, práce v týmu;

- poznávání vlastních možností;

- prezentace vlastních výsledků;

- osobní zkušenost;

- přechod od frontálního vyučování k aktivizujícím metodám;

- praktická cvičení;

- dodržování etiky komunikace (věcnost, naslouchání, prostor pro různé názory, respektování originálních, nezdařených aj. názorů);

- předpoklad poznávání sebe a vztahů k jiným.

Při tvorbě ŠVP jsem s ředitelem školy polemizoval nad tím, zda čas, který na 1. stupni strávíme nácvikem a osvojením slohotvorných útvarů, bude:

1. respektovat vytyčené výchovné a vzdělávací strategie;

2. směřovat skutečně k rozvíjení zejména a) kompetencí k učení; b) sociálních a personálních klíčových kompetencí (práce s textem; formulace vlastního názoru; kritické myšlení; čtení s porozuměním a práce s textem; využívání zájmu žáků; formování vlastních názorů a jejich prezentace; vhodná komunikace se spolužáky, s učiteli a ostatními dospělými ve škole i mimo školu; diskuze a naslouchání názorů druhých).

Z těchto důvodů jsme se rozhodli pro zařazení autorského čtení jako alternativního přístupu do komunikační a slohové výchovy.

V následující kapitole je $\mathrm{z}$ důvodu porozumění kontextu nutné tuto disciplínu teoreticky představit a specifikovat její dva hlavní rozdíly oproti tzv. „tvưrčímu psaní“.

\section{Fenomén autorského čtení}

V 90. letech se začíná i v Česku prosazovat jiný termín, který autorské čtení může evokovat: tzv. „tvưrčí psaní, popřípadě „autorské psaní“. Jedná se ale o jinou disciplínu. S velkým zjednodušením můžeme konstatovat, že tvůrčí psaní je primárně zaměřeno na umělecký artefakt. Cesta $\mathrm{k}$ tomuto artefaktu je zvnějšku řízena aplikováním metod či technik: tedy přes podané pracovní postupy a návody pro tvoření textů v daných oblastech. ${ }^{18}$ Primárním cílem tvưrčího psaní je estetická kvalita textu, i když se počítá i s formativními vlivy na osobnost autora textu. Součástí tvưrčího psaní je i sebereflexe. Na rozdíl od autorského čtení je ovšem účelová a má předem daný cíl. Cílem sebereflexe je ve tvůrčím psaní zhodnotit proces. Ve filozofii tvưrčího psaní je tvořivostí vlastnost, kterou lze technicky rozvíjet, zejména tzv. heuristickými technikami zaměřenými na 
jednotlivá stadia řešení úloh a jejich vývoj. ${ }^{19} \mathrm{~V}$ přístupu je tvưrčí psaní v českém prostředí podobné dramatické výchově. ${ }^{20}$ Tvůrčí psaní vzniká s dramatickou výchovou v podobné době a obě metody jsou ovlivněny stejnou behaviorální optikou v př́stupu k jedinci (osobnost lze zvnějšku formovat metodicky a technicky).

Autorské čtení se liší od tradičně chápané slohové výchovy a od tzv. tvưrčího psaní v prvé řadě tím, že nepohlíží na žáka behaviorální optikou. Behaviorální pedagogické tendence vysvětlují dynamizaci vnitřní síly jedince mechanismem: úkol $\rightarrow$ úspěch $\rightarrow$ ocenění. ${ }^{21}$ Pedagog je $\mathrm{v}$ tomto pohledu chápán jako „strategický manager“, který zadává úkol: konkrétní (výchovný) cíl určený ke zhodnocení (dle různě zaměnitelných kritérií). Úspěch ve školní situaci je přitom brán za hlavní motivační faktor dávající žákům sebevědomí k opakování činnosti a podávání výkonu dle zadaných parametrů. Behaviorální pohled na problematiku pedagogického působení ovšem není dost široký v momentě, kdy akcentem není výkon jako takový (kvantitativní hodnota), ale pedagogickým akcentem je rozvíjení takových vloh žáka, které podléhají kvalitativním měřítkům. Typické (i když poněkud tematicky zprofanované a vágní) je deklarování pedagogického zaměření na žáky jako takové (na jejich osobnost), tedy nikoliv na jejich prospěch (viditelné, měřitelné chování). Zaměření na rozvíjení osobnosti žáků se stalo námětem mnoha přístupů zasahujících výrazně do pedagogické reality (např. formou dramatické výchovy či etické výchovy: disciplínami a metodami, které jsou vedené jako doplňující pro vzdělávací obor RVP).

Zmiňované behaviorální (pedagogické) prŕístupy mají velmi blízko k tzv. teorii rolí a jsou specifické tím, že svým pojetím obvykle redukují osobnost jedince na způsoby chování a prožívání, v nichž jedinec vyjadřuje svou představu o tom, co odpovídá očekávání vztahovanému k určitým životním pozicím a situacím. ${ }^{22}$ Dle Drapely by v optice psychologie osobnosti šlo o tzv. vnější vztažný rámec pro studium chování: ten sice umožňuje měřit a hodnotit chování jako normální (kýžené) či abnormální (zralost osobnosti je takto chápána v pojmech jako je „sociální přizpůsobeni“'), osobní svoboda volby je ale výrazně omezena činiteli (vnějšími či vnitřními). ${ }^{23}$

Autorské čtení je svým pojetím k výše zmíněnému protikladné: filozoficky má blízko k humanistickým teoriím osobnosti, ve kterých není hlásáno výrazné omezení osobní svobody a volby vnějšími či vnitřními činiteli. Osobností je ten, kdo je autorem svých činů: „osobností je člověk potud a natolik, pokud a nakolik jeho činy vycházejí z něho samého, pokud vyjadrùjí jeho poznání, jeho zkušenost, jeho dovednost a nejsou jen mechanickým napodobením, kopií nějakého vzoru. "24 Druhý hlavní rozdíl je v tom, že v autorském čtení nejde primárně o „hezký text“, ale o objevování sdělnosti „skrze text“ pro čtenáře i diváka v konkrétní situaci. Jde tedy v první řadě o vlastní možnost jedince objevovat (a v setkání s druhými uplatňovat) své tvůrčí potencionality a tématizovat vlastní sdělení.

Paradox autorského čtení vysvětluje V. Fryntová lapidárně: pouhé přečtení autorského textu samo o sobě nezaručí, že je autor k posluchačům sdělný. Nejde přitom v první řadě o žánrovou kvalitu textu, ani techniku čteného, ale o představu čteného: „Jak podivné. Vždyt autor snad ví, co napsal, co řekl, kde to bylo. To je mu všechno jasné, ale my posluchači autorského čtení obvykle neslyšíme, že by mu to skutečně jasné bylo. Jak je to jenom možné? Možným vysvětlením je, že autor již text

19 Pavla PAZDERNÍKOVÁ, Tvưrčí psaní a vědecká práce. Brno, 2009. Disertační práce. Masarykova univerzita. Filozofická fakulta. Ústav české literatury a knihovnictví. Vedoucí práce PhDr. Zbyněk Fišer, Ph.D., str. 29.

20 Např. Eva MACHKOVÁ, Metodika dramatické výchovy, Praha: IPOS ARTAMA, 1999; Josef VALENTA, Osobnostní a sociální výchova, Kladno: Aisis, 2005.

21 Srov. Geoff PETTY, Moderní vyučování, Praha: Portál, 1996, s. 40.

22 Srov Vladimír SMÉKAL, Pozvání do psychologie osobnosti, Brno: Barrister \& Principal, 2007, s. 33.

23 Srov. Victor J. DRAPELA, Přehled teorií osobnosti, Praha: Portál, 1998, s. 158.

24 SMÉKAL, Pozvání..., s. 33. 
napsal. Jak by úplně všechno zahodil s vědomím, že má po šichtě a naprosto nemyslí na to, že když ten text psal ve své sluji s nohama nahoře, že toto všechno prožival, dokonce intenzivněji, než jakýkoli herec! Vždyt on by to nemohl napsat, kdyby neměl onu představu. Jenom onu představu vůbec nepoužívá. (...) Paradox autorského čtení nám tak ukazuje, že ke čtení je třeba navíc ještě něco jiného než pochopení textu, než srozumění s autorem a pochopení smyslu sdělení. "25

Disciplína autorské čtení je velmi podivuhodná. Podivuhodná tím, že artefakt vytvořený ze slohových struktur je až sekundárním jevem, primární kvalitou je sdělnost autora konkrétního textu. Jádrem autorského čtení tedy není psaní, ale čtení: autorem vytvořená situace mezi ním a posluchačem/posluchači, která je základem pro dialog (dia-logos, srozumění „skrz slovo, smysl“).

Ke kultivaci autorských textů je proto třeba texty ověřovat veřejně. Zatím se podařilo reflektovat dlouhodobou zkušenost s dospělými. Zejména se studenty pedagogických oborů (odkazuji tímto na články S. Sudy, který shrnoval data získaná od studentů z Jihočeské univerzity v rámci dlouhodobého studia tzv. experimentální dramatiky).

Realizace autorského čtení u dospělých posluchačů má jednoduchá pravidla: skupina studujících si své texty vzájemně čte a komentuje nehodnotícím způsobem. Posluchači tak poskytují autorovi textu pozornost $\mathrm{k}$ tomu, aby na základě veřejného jednání objevoval skrze vlastní text osobní téma a hledal $\mathrm{k}$ němu potřebnou sdělnost. Počáteční zadání je $\mathrm{v}$ rámci kurzů pro studenty děsivě volné. „Pište, co chcete, délka textu, forma a žánr je na vaší chuti.“ Dospělí studenti vychovaní v pravidlech slohotvorných postupů bývají obvykle naprosto konsternováni svobodou, která se nabízí. Opakovaně se nám potvrzuje to, že určitá struktura dává bezpečí - někteří studenti raději volí klasickou „slohovku“ (úvod; stat; závěr) nebo se v řádcích vyjadřují k tíživému úkolu, že bez konkrétního zadání nemají o čem psát. $\mathrm{V}$ postojích se objevuje i podrážděnost $\mathrm{z}$ nejednoznačnosti. ${ }^{26}$ Postupem času ale všeobjímající strach obvykle mizí, studenti objevují zájem: činnost samotná se stává hybnou silou $\mathrm{k}$ dalším pokusům.

Bylo jasné, že má-li být přenesení disciplíny autorské čtení do prostředí 1 . stupně ZŠ úspěšné, žáci mladšího školního věku budou vyžadovat odlišný přístup, než jaký byl zatím zažitý u posluchačů vysokých škol.

V následujících kapitolách se proto budu snažit popsat, jak se základní principy zmiňované disciplíny dařilo přenést do prostředí 1 . stupně ZŠ (jako určitá alternativa komunikační a slohové výchovy) a s jakými výsledky.

\section{Objevování autorského čtení na 1. stupni ZŠ}

Jak již bylo řečeno: základní instrukce autorského čtení je otevřená, nenařizuje se téma, rozsah textu, obsahové zaměření či způsob použití stylistických prostředků. Poté je text čten ostatním posluchačům a na základě pozornosti od ostatních se autor textu dozvídá, jaké kvality jeho text má. Na základě zážitku $\mathrm{z}$ tohoto veřejného čtení poté posluchači formulují písemné sebereflexe, kterými mapují svou studijní cestu.

Běžnou praxí základních škol je, že komunikační a slohová výchova je vyučována nahodile dle tematických plánů vyučujících, popř́ípadě blokově. Při tvorbě ŠVP jsme chtěli, aby autorské čtení

25 Vítězslava Ada FRYNTOVÁ, O paradoxu autorského čtení, in: HIC SUNT LEONES (O autorském herectví), ed. Michal ČUNDRLE, Praha: AMU, Ústav pro výzkum a studium autorského herectví při katedře autorské tvorby a pedagogiky, 2003, s. 67.

26 V rámci kvalifikační práce (Josef NOTA, Dialogické jednání jako možnost rozvoje osobnostních dispozic učitele. České Budějovice, 2014. Disertační práce. Jihočeská univerzita v Českých Budějovicích. Pedagogická fakulta. Katedra pedagogiky a psychologie. Vedoucí práce doc. MgA. Stanislav Suda, Ph.D.) se ve výzkumu ukázalo, že strach z nejednoznačnosti v zadání úkolu byl v osobnostní př́pravě na pedagogickou profesi typickým faktorem pro absolventky středních pedagogických škol. 
bylo kondiční věcí, tedy aby se stalo nedílnou součástí týdenního rozvrhu.

Brzy jsem zjistil, že vývojová charakteristika žáků mladšího školního věku neumožňuje, aby byla základní instrukce naprosto otevřená. Autorské čtení proto v prostředí ZŠ realizujeme následujícím způsobem: ke konci výukového týdne mají žáci př́ležitost $k$ vymýšlení témat, které je samotné fascinují. Má úloha spočívá $\mathrm{v}$ tom, aby náměty $\mathrm{k}$ textům: 1 ) byly tematicky dostatečně otevřené a probouzely fantazii a chut ke psaní; 2) vznikaly výhradně z nápadů dětí; 3) procházely pedagogickou korekcí jen v př́padě, že jejich potenciál je eticky, mravně závadný.

První dva roky autorského čtení jsem děti nechával, aby si hlasováním zvolily jedno společné téma z nabízených sepsaných možností. Zjistil jsem ovšem na základě rozhovorů $s$ rodiči, že děti, které hlasovaly pro téma jiné a musely se podřídit tématu s největším počtem hlasů, nepiš́i texty s radostí a se zájmem. Velmi se mi proto osvědčilo nechat výběr konkrétního tématu ze všech nabízených na jednotlivcích. Většina „pokročilých“ si již „jede“ téma vlastní bez ohledu na ta „oficiálni“", která se zformulovala společně. Využívají nabízenou autorskou svobodu k pokračování př́íběhů, dětem tak vznikají celé kapitoly, které na sebe tematicky navazují.

I v prostředí ZŠ se klade důraz na ideu, že základem a samotným jádrem takto vedených setkání je nikoliv samotný napsaný artefakt určený ke zhodnocení učitelem, ale veřejné, hlasité čtení. Cílem je učit se poslouchat druhého, pokládat doplňující otázky. Autoři textů se učí na doplňující otázky reagovat. Činnost je sama o sobě zdrojem pro rozvíjení posluchačské a čtenářské sdělnosti.

Autorské čtení vyžaduje čas, $\mathrm{v}$ našem případě skupina 12 dětí potřebuje na soustředěné setkání nejméně dvě na sebe navazující vyučovací jednotky. I ty se ale dále rozdělují na „oddechový čas“ zpestř̌ený jinými aktivitami (např. zpěvem autorských písní), protože je empiricky známo, že děti mladšího školního věku nejsou schopné udržet plnou pozornost celou formální vyučovací jednotku.

Když bylo dětí ve škole méně, motivoval jsem k prvním autorským pokusům i žáky, kteří ještě nebyli čtenářsky gramotní. O vybraném tématu hovořili ústně, přičemž si jako oporu pro své myšlenky kreslili obrázky do sešitu, popř́padě si vzali s sebou do školy nějaký artefakt (hračku, předmět). Vedl jsem je tedy již od 1 . tř́dy $k$ tomu, aby se pokoušeli v rámci svých možností vyjadřovat před ostatními a poslouchat druhé - aby měli již od 1 . tř́ídy základ $k$ veřejnému, autorskému jednání. Autorské čtení jsem po 4 letech začal praktikovat pouze s dětmi 3.-5. ročníku, přičemž hlavním důvodem byl zvyšující se počet dětí ve skupině, jak se škola začala rozrůstat.

Jelikož se na tyto hodiny připravují doma, pro co největší smysluplnost těchto setkání jsem o pomoc požádal rodiče žáků otevřeným dopisem. ${ }^{27}$

27 ... Děti za své texty nejsou ve své podstatě hodnoceny, nebot kritéria kvalitního textu se nedají vyjádřit známkou (např. Božena Němcová psala na jedničku, Alois Jirásek na dvojku). Dostanou-li známku, je myšlena pouze jako motivační věc ... Naším společným úkolem zde, na 1. stupni ZŠ, je vzbudit u dětí zájem a důvěru, že psát (a vůbec formulovat vlastní myšlenky před ostatními) mohou (dítě talentované se může stát spisovatelem, dítě bez zájmu a zklamané si může vztah $\mathrm{k}$ jazyku, literatuře a čtení vytvářet v bezpečném prostř̌edí) ... Žák, který tuto důvěru ve své schopnosti nemá, zpočátku tento typ textu zřejmě vůbec nenapíše. Touto cestou prosím o velkou trpělivost s dítětem, kterou si i já sám na sobě při našich hodinách testuji. Pokud dítěti text napíšete a nadiktujete, zvládl jste zadání Vy, ale nikoliv dítě. Je to pro něj do budoucna jasná informace, že nedostačuje a Vás příště bude potřebovat. Ocitáte se pak v začarovaném kruhu, kdy (a nyní to berte s nadhledem) „kvůli učiteli, který si vymyslel nějakou blbost“ se každý čtvrteční večer budete stresovat s tím, aby ratolest něco napsala, aby „učitel měl radost“ ... O to ale vủbec nejde. Nejde nám o to, aby text „byl pěkný“, ale aby ho dítě napsalo samo, protože ho to posunuje vpřed, pak to má cenu ... Jakpak na to? Zpočátku může být opravdu dítě nad papírem neštastné, zvláště pokud si nevěří, že něco napsat samo může. Naším společným úkolem je ho povzbudit a dodat sebedůvěru. Zpočátku možná napíše tř̌i věty, což je ohromné vzhledem $k$ tomu, že dříve nenapsalo vůbec nic. Doporučuji důrazně dítě netrápit nad papírem, ale "rozmluvit ho“ otázkami směřovanými k tématu, pokud možno úplně přirozeně. Ono něco zformuluje - nedělejme si s tím zpočátku hlavu. Doporučuji dítěti nevkládat do hlavy, v případě těchto textů, vlastní myšlenky. Například pokud mu v tématu „Kdybych byl na Marsu“ řeknete, že mimozemštani jsou pitomost, kterou si vymysleli šílenci, a neexistují, dítě Vaše slova do textu odpapouškuje, ale v rámci výše zmíněného mu to nic nedá, nebot jste mu téma uzavřeli. Důležité je naopak ho povzbudit, aby napsalo, co si myslí - klidně s opřením o Vaše názory - ovšem cílem není polemika na téma, jestli jsou mimozemštané. Nám jde o literární, autorský, dítětem vymyšlený text, který nemusí odpovídat pravdě. Alois Jirásek také napsal O králi Ječmínkovi a J. R. R. Tolkien dokonce celý fiktivní svět. Je třeba zmínit k budoucím 
Získání príizně rodičů pro tento typ experimentální výuky bylo naprosto kličové: důležitý byl opakovaný dialog s rodiči o filozofickém zázemí autorského čtení a o celkových přínosech. Opakovaně mi ovšem někteří rodiče sdělují své obavy: „A nebude jim chybět to, že pořádně necvičí, co je „vyprávění a „charakteristika“...? Tak tomu ale není: to, že se primárně nevěnujeme nácviku slohotvorných útvarů, neznamená, že je úplně opomíjíme. Výhodné ale zpravidla je, když základem k výkladu bývá napřed nějaký autorský text, na kterém se poté dá konkrétní slohotvorný útvar snadno popsat.

V následujících kapitolách bude reflexe zkušenosti s autorským čtením (hledání odpovědi na hlavní výzkumnou otázku) ilustrována za pomoci př́ípadových studií dětí.

\section{Příklad č. 1: bystré, svérázné dítě s výborným prospěchem}

Pedagogické pozorování: od 1. třídy naprosto samostatný, sám si iniciativnè organizoval školní práci (v rámci málotř́dní školy je nutné, aby část žákư vždy pracovala samostatně, zatímco pedagog se věnuje skupinè druhé, napṛ̌. podáváním výkladu nové látky). Výsledky excelentní.

$V$ rámci naši málotřídní školy je akcent na podporu učení mladších dětí dětmi staršími (žáci 5. ročníků doučuji např. žáky 2. tříd). Při této „výukové činnosti Martin postrádal potřebnou trpělivost. Aktivně ale vztahy s ostatními nebudoval, nebyl za každou cenu kontaktní. V kolektivu dètí velmi oblíben, v pedagogickém sboru také (výrok ředitele: „Spís chybí asi víc on mè, než já jemu. “), obdivován za sportovni úspěchy. Maminka ho hodnotí jako zbytečně sebevědomého, málo pracovitého („Vy to ve škole možná nevidíte, ale doma neudělá nic, neuči se, nepripravuje, fláká to."). Disponovaný svérázným, ironickým humorem.

Málotřídní školu opustil před rokem s výborným hodnocením, pokračuje studiem na víceletém gymnáziu.

Pokud se dá považovat disciplína autorské čtení za specifickou možnost k vlastnímu experimentu, Martin této možnosti bezpochyby maximálně využíval.

Už od 3. třídy byl jedním z hlavních iniciátorů nových témat, jeho čtení téměř ihned získalo mezi spolužáky trvalou oblibu pro hravou teatrálnost. Veškeré své texty „posadil do hlasu“ (držel brániční hlasovou oporu) a poté četl absolutně bez stoupající či klesající intonace. (Ředitel: „Když jsem vás slyšel, jak čtete, byl jsem u vytržení, ale nad Martinem jsem žasl. Obsahově tak zajímavý text a čtený tak unyle a otráveně, že se jednalo o vrcholný komediální výstup. Martina poslouchali po celou dobu úplně všichni. Držel prostě svůj styl.“).

Přibližně po roce autorského čtení Martin zjistil, že ho jeho „běžné autorské texty“ (tematicky zaměřené, s jasnou dějovou linkou, dobře vypointované) přestávají uspokojovat a začal si svůj předchozí, před rokem objevený autorský styl plánovitě ničit. Např́íklad napsal tři dlouhé věty, přičemž u slov protáhnul samohlásky. Jednalo se vlastně o takové „textové a čtecí excesy“, ovšem $s$ veškerou výrazností Martinova přednesu se stávaly nesmírně populární. A samozřejmě i ostatními spolužáky kopírované. Po měsících mi volala Martinova maminka s obavami, že Martinovo psaní už postrádá jakékoliv kvality jeho předchozí tvorby („Píše už jen kraviny, já ho asi za to zabiju."). Navrhnul jsem vyčkávat. Po dalších dvou měsících zmizely prvoplánové teatrální výstřelky. Místo toho Martin zjistil, že civilnější texty i přednes mu dávají možnosti ve variování dramatiky a především $v$ tom, že začal cítit potřebu psát př́běhy se silnou pointou. To realizovat s kašpařením nejde. 
Martin mi ukázal: 1) jakou výhodu má autorské čtení v momentě, kdy má „tahouna“: někoho, kdo ostatní iniciuje k diskuzi, sám je originální, sdělný a podněcuje tvůrčí skupinovou dynamiku; 2) možný prediktovatelný vývoj, který mohou autorské experimenty mít.

S Martinem jsem si uvědomil, že jádro autorského čtení není v instrukci, kterou děti splní. Jádrem je situace, kterou děti svým čtením ostatním vytvářejí. V tomto byl Martin ohromný: měl ke tvorbě vlohy, byl motivovaný, a když se mi dařilo ukočírovat i jeho přirozeně ironický smysl pro humor (který byl zejména pro mladší děti těžko stravitelný), spoluvytvářel vstřícnou atmosféru bez bariér z falešných emocí.

\section{Příklad č. 2: zkušenost $s$ dítětem, které má negativní zkušenost z předchozí školy}

Evička (9 let) pochází z úplné rodiny, má další 4 sourozence. Ze sdělení rodičư: rodiče umístili Evičku do naší školy $v 8$ letech; nutnost změnit školu zdůvodňovali tím, že Evička byla na předchozí škole neštastná - její bývalá třídní učitelka prý Evičku přetěžovala a vytýkala jí neopodstatněně marginálnosti. Zmínèné pedagogické apely $v$ důsledku vedly $k$ tomu, že Evička začala somatizovat (byla nemocná dokonce i každý měsíc). V naší škole je druhým rokem, autorské čtení má (dle jejího tvrzení) ráda, v současné době protipandemických opatření jí setkání s dětmi při čtení autorských textů moc chybí.

Evička je v projevu extrovertní, bez obtíži komunikuje s dospělými, při hře s dětmi iniciativní, vìdčí. Při školní práci velmi aktivní, výkonová motivace u ní ale nedominuje.

Když se Evička seznámila s autorským čtením, zpočátku se opakovaně potřebovala ujistit, že skutečně může psát sama za sebe („A co když to budu mít špatně?“). Její první texty byly vedeny konvenční strukturou (úvod, stat', závěr). Po třetím autorském čtení se v Eviččiných textech objevila hlavní postava Simony. Z ní postupně udělala hlavní hrdinku dalších textů, po roce psaní pokračuje v jakémsi typu „románového psaní, ve kterém Simona zažívá nevšední dobrodružství. Kapitola o holčičce Simoně, kterou si Evička připravuje na setkání autorského čtení, má v současné době rozsah cca 3 strany A5 rukopisu.

Čtení velmi výrazné, hlasité, na každé setkání se těší. Když dává Evička zpětnou vazbu spolužákům, je přehnaně kritická a uvádí obsahové alternativy $\mathrm{k}$ obsahům přečtených textů („Já bych to napsala jinak..."). Přehnaně kritická i k vlastním textům.

Když jsem Evičku vyzval, aby mi povídala, jaký vztah má k autorskému čtení, ve výpovědi dominovalo srovnávání její bývalé a současné školy:

Evička: Jak jsem byla v minulej škole, psát slohovky mě nebavilo, protože jsme to (slohy) měli jen někdy. A pořád jsme slyšeli, že to neumíme a nemáme to psát moc dlouhý. A nemohli jsme vưbec ríct, co chceme. Když jsem nastoupila do této školy, tak se to změnilo. A začalo bavit. O hodně víc. Já: Co ale znamená to „nemohli jsme říct, co chceme“?

Evička: Prostě - když jsem něco psala, musela jsem to (zadání) splnit. Napsat to přri hodině. A když jsme to neměli tak, jak to přsně učitelky chtěly, tak jsme prostě dostali pětky a bylo jim (učitelkám) jedno, co jsme chtěli my.

Já: A četli jste si své texty vzájemně?

Evička: Ne, jen to učitelka zkontrolovala a nechala to bejt.

Já: A co se kontrolovalo?

Evička: Zkontrolovala nám chyby - tedy pravopis - a potom kontrolovala, jestli jsme to udělali podle 
jejích představ a tak vỉbec. ${ }^{28}$

Evička si příležitosti, kterou jí nabízí autorské čtení, užívá. Její případ mi pomohl v tom, abych si zformuloval, jak hodnotící prostředí a tlak na předem zformulovaný produkt mohou v součinnosti blokovat potencionality, které v sobě děti mohou mít.

\section{Př́iklad č. 3: zkušenost se silně úzkostným dítětem}

Od 1. tř́dy se Pavel projevoval silně introvertně, úzkostně. Podle maminky měl již od raného dětství komunikační obtiže, které začaly být zřetelnější nástupem do vzdělávacích institucí. Těžko snášel kritiku, na př́padný neúspěch okamžitě reagoval pláčem, poprípadě útěkovou reakcí (schovávání pod stůl, útěk ze třídy, vyhledávání úkrytů). Měl již od 1. třídy slabý výkon, podle ředitele školy byla přičinou nízká frustrační tolerance, zbytečně brzy se při řešení problémových úloh vzdával, plakal nad úlohami, nepracoval. Sohledem na evidentní studijní vlohy nebyl první dva roky ve své podstatě vỉbec klasifikován, byl hodnocen pouze slovnè.

Ředitel školy: „Já myslím, že je zázrak, že jsme ho neubili - špatnými známkami i reálnè - hned v 1., 2. či 3. tř́dě. Byl chytrý, ale v zásadě zoufale emocionálně nevyzrálý. Pak ale ty svoje záchvaty pláče začal zvládat, bylo jich méně a méně. (...) Spouštěěem toho pláče bylo prakticky cokoliv. Volali mi i ze ZUŠ, jestli nemají s bráchou špatné rodinné zázemí.

$V$ 5. ročníku Pavel začal mít spontánní zájem o výuku, ve školní práci byl iniciativní, začal mít nadprůměrné výsledky. Podle individuálního plánu vše zameškané dohnal. Jak glosoval ředitel: „Rodiče jsem první čtyři roky uklidňoval, že se to poddá. Naštěstí to klaplo."

Do skupiny autorského čtení přišel ve 3. třídě. Je běžné, že zpočátku žáci 3. ročníků sami za sebe napíši maximálně 3-5 vět, než objeví jistotu ve vyjadřování a zjistí, že si mohou troufat, rozepsat se a při čtení své sdělení ověřovat. Pavel se svými třemi větami vydržel celý školní rok. Navíc: přemluvit Pavla $\mathrm{k}$ jejich přečtení bylo náročné, někdy se ještě před autorským čtením schoval pod stůl a celou vyučovací jednotku odmítal vylézt. Maminka z nás byla nejzoufalejší, vyprávěla, jak prríprava těch pěti vět je pro něj celodenním utrpením a jak se bojí, že bude muset své texty číst před ostatními nahlas. Na konci 3. ročníku nebyl vidět žádný vývoj - ve čtení, ani v textech. Ve 4. ročníku Pavel jen objevil strategii vedoucí k tomu, aby nemusel číst nahlas: dával své texty $\mathrm{k}$ předčítání svým spolužákům. Interpretoval jsem to jako další z Pavlových únikových strategií, kterou jsem podporovat nechtěl. Pavla jsem do hlasitého čtení jeho textu před ostatními spolužáky nenutil, ale domluvil se s ním na alternativě: přečte text jen nám, učitelům. S tím problém neměl, zřejmě tušil podporu. Kvalita textů zůstávala na nízké úrovni, Pavel vlastně jen formálně splnil požadavek: měl mít něco napsáno a měl to přečíst ostatním. Př́liš jsem si s tímto stavem nevěděl rady - s rodiči jsem se domluvil, že to tak zatím necháme...

V 5. ročníku se s Pavlem něco velmi podstatného začalo dít. Přišel za mnou, zda mưže přišstě místo čtení textu ostatním spolužákům promítnout na plátně, co naprogramoval v jakési počítačové aplikaci. Jednalo se o triviální skeč: objevila se kreslená postavička, které se vytvořila u úst bublina s textem, zahrála hudba a obraz skončil. Otevřel jsem prostor pro diskuzi k Pavlovu autorství, jako kdyby se jednalo o přečtený text. A začaly se dít věci. Pavlovi spolužáci byli evidentně v šoku, že se Pavel aktivně projevil a nešetřili uznáním. Pavel nedal na sobě znát vůbec nic, ale na příští hodinu přinesl další, podobnou naprogramovanou črtu. Ale trochu delší, podle maminky nad ní strávil kolem 8 hodin svého času. Maminka měla hlavně obavu, co na to budu říkat, a zdalipak Pavel zase od zadání neutíká. Ve mně naopak rostla naděje, že snad jen Pavel objevuje, jak si

28 Citovaný úryvek s žákyní je z hloubkového nestrukturovaného rozhovoru ze dne 12. 6. 2020. 
zadání přizpůsobit. Upřímně: ve své podstatě se nedalo nic ztratit - před zmíněným promítáním byl Pavel velmi vzdálen tomu, co je cílem i smyslem autorského čtení. Přibližně po měsíci pouštění naprogramovaných postaviček se objevil další milník: animované postavičce v programu dal Pavel svou hlavu, elegantní způsob, jak za sebe Pavel nechal v zastoupení jednat. Kolem pololetí 5. ročníku bylo posledním objevem Pavla natáčení vlastních videí z prostředí maloměsta, kde $\mathrm{Pa}$ vel vyrůstá. Pavel se pasoval do role režiséra, někdy ve svých scénkách sám hrál. Získal pro svou tvorbu několik kamarádů, kteří mu dělali herce a komparz, natočený materiál sám sestř́hal, poté pouštěl své rodině a nám ve škole na hodinách autorského čtení.

Do této doby jsem měl odpozorované, že autorské čtení v době mladšího školního věku má u dětí určitý vývoj: od prvních nestrukturovaných, plachých pokusů, přes konvenční texty s šablonovitou strukturou, až po texty experimentální, invenční, osobní. Vývoj měl i Pavel se svým typem autorské tvorby, který si sám pro sebe objevil a před ostatními ověřoval.

Pro mě jde o zjištění, že hledání způsobu vyjádření a vlastní tvorby nemusí jít přímou cestou a nemusí jít přes disciplínu autorské čtení. Jsou jedinci, kteří raději stojí za kamerou než před ní. Pavel opustil naší školu minulý rok. Rozhodl se, že na základě zkušenosti s jeho alternativním př́stupem k autorskému čtení (kdy spíše autorsky natáčel filmy) je jeho cílem stát se kameramanem. Tak uvidíme. Pavla maminka nám v posledním rozhovoru jeho rozhodnutí potvrdila: „Našel si i školu a prostě chce."

\section{Příklad č. 4: zkušenost s dítětem, které má snížené studijní předpoklady}

Z pozorování ředitele školy: Mareček je „vymodlenýc chlapec narozený do úplné rodiny, má sestru starší o 5 let. $V$ rodině byl na úkor své starší sestry velmi protěžován.

Již u zápisu do 1. tř́dy vykazoval známky emoční nezralosti, rodičùm byla citlivě sdělena predikce možných výukových obtižzí, práli si ovšem řádný nástup Marečka do školy v jeho 6 letech. U Marečka byly vždy zjevné logopedické vady, které škola téměr úplně odstranila v rámci zaplacené logopedické prevence $v$ jeho 10 letech (do té doby s ním rodiče logopedii $z$ vlastní vủle i přes doporučení školy nenavštivili). Od začátku školní docházky u Marečka dominovaly problémy dané emoční nevyzrálostí a sníženými studijnimi predpoklady. Obsahy učiva hlavních předmètů chápal pomalu nebo vůbec, komunikoval triviálnè, při nácviku čtení trpèl oslabenou schopností analýzy/syntézy ( $v$ rámci školní družiny s ním pedagogové pracovali s materiály vhodnými pro prevenci dyslektických obtiží). Rodiče kvitovali navrhovanou možnost diagnostiky Marečkových studijnich obtiži pedagogickopsychologickou poradnou, návštèvu tohoto pracoviště ale nikdy nezrealizovali. Postupem času rodiče zminěné pretrvávajicí obtiže začali bagatelizovat, popřípadě hledat príčiny v nerozvinutých motivačních strukturách („Von je chytrej, ale nechce.").

$V$ kolektivu reagoval vznětlivě, popudlivě, neuměl prìimout neúspěch. Za dobu povinné školní docházky na 1. stupni se nám, pedagogům, úplně nepodařilo odbourat jeho zlozvyk tkvící v tom, že na každou položenou otázku otevřel ústa dokořán a získával čas na odpověd tím, že odvětil prodlouženým "Cooooooooo?". Evidentně psychomotoricky nadaný, tatínek ho podporoval k hraní fotbalu, kde měl velkou príležitost zažívat úspěch. Zajímavostí bylo přenášení naučeného neetického jednání z tohoto kolektivního sportu do školního prostředí (simulování zranèní při venkovních hrách, hysterické, verbálně agresivní hádky o správnosti/nesprávnosti počínání druhých apod.).

Školu opustil před dvěma lety s dostatečným prospěchem, školní rok na 2. stupni v současnosti opakuje.

Mareček nastoupil do skupiny autorského čtení od 3. tř́dy a okamžitě začal nosit „slohovky“, tedy 
konvenčně strukturované práce ve stylu úvod/stat'/závěr. Většinou se jednalo o vyprávění s jednoduchou pointou. I když byl text psán Marečkovým písmem, Mareček bojoval s vyluštěním sdělení skrývajícího se mu ve větách, minuty se vlekly, než Mareček konečně přečetl text, kterému i on sám vůbec nerozuměl. Ten rozpor mezi tím, jak se Mareček běžně ústně vyjadřoval a tím, co měl $\mathrm{v}$ textu, svědčilo o náročné rodičovské intervenci. Já: „Marečku, pomáhala mamka nebo tatka?“ Mareček: „Coooooo?“ Já: „Marečku, mluvím o tom textu, je napsán opravdu dobře, jen by bylo prima zlepšit čtení, abychom mu lépe rozuměli. Pomáhal Ti s ním tatka nebo mamka?" Mareček: „Voba.“

I přes několik rozmluv s rodiči Marečka nad tím, že Mareček není ode mne žádným způsobem klasifikován a že smyslem autorského čtení není napsání pěkného textu, ale skutečně čtení, které je námětem $\mathrm{k}$ dialogu mezi dětmi, autorské čtení zůstalo pro Marečka chvílí, kdy nemohl jít ven, aby si kopal do míče. Protektivní rodičovská př́prava textů pro Marečka byla analogická s př́pravou jeho svačiny na pravidelné fotbalové tréninky. Autorské čtení tak pro Marečka nikdy nebylo ani autorské a vlastně se ani nejednalo o čtení s potřebnými kvalitami. Asi k tomu nejvíce chyběla trpělivost na straně všech zúčastněných.

\section{Příklad č. 5: zkušenost s citově deprivovaným dítětem}

Bertíkovi rodiče se rozhodli, že syna nesvěři do péče městské škole v mistě jejich bydliště. Dưvodem byla negativní zkušenost, kterou zažili, když do této městské školy chodil Bertíkưv starší bratr (maminka: „Nechtěli jsme, aby i Bertík nosil domi̊ jen poznámky. “).

Rozhodli se proto, že bude raději Bertík každý den $15 \mathrm{~km}$ dojiždět do naší školy a bude v menším kolektivu. Bertíkův bratr ( $v$ současnosti 17 let) byl do náhradní rodiny adoptován jako první ve věku cca 3 let, do té doby byl umistěn $v$ dètském centru. Bertík byl těmito náhradními rodiči adoptován přibližně v dobè, kdy mu byl půlrok. Oba bratři (mají stejnou biologickou matku, různé biologické otce, věkově od sebe vzdáleni 5 let) vykazují i pres veškerou péči osvojitelü známky hluboké citové deprivace.

$V$ kolektivu dominantní, manipulativní, neoblíbený, v př́padě slabé vnějši kontroly pedagogického týmu měl sklony $k$ asociálnímu chování (např. když byl pozván spolužákem na narozeninovou oslavu, oslavenci ukradl penize, aby si koupil kofolu). Kdyžjsem ostatníčleny našeho pedagogického týmu požádal o volné vyprávění o Bertíkovi, nebylo to snadné (ředitel: V rozhovorech o Bertíkovi je náš pedagogický tým mlčenlivý.). „Je to chvíle, kdy má vychovatel pocit, že soustavně selhává. Vystř́li iš veškeré výchovné prostředky, domlouváš, vysvětluješ, ale on Ti lže. Situace jako na policii u výslechu. Nakonec se rozpláče, tak zjihneš. A za pět minut jdeš zase řešit, komu ubližil."

Bertíkovi rodiče měli z volnosti, kterou dává prostor autorského čtení velkou starost: „My bychom potřebovali konkrétní, nezávadná témata. Jestli by to nevadilo, budeme mu do toho mluvit. Hodně mluvit."

Jako veškerá Bertíkova činnost, tak i Bertíkovi texty byly podrobovány silné rodičovské cenzuře z obav, že se artefakt morálně zvrhne. Na našich setkáních s autorským čtením je Bertík předčítal sice korektně, ale nezaujatě, odosobněně. Jen tu a tam v nich totiž obsahově vystupovaly jeho velké vášně: zbraně, válečné násilí a skrytá fascinace sexismem. V rodičovsky cenzurovaných textech plné neutrálně zabarvených obsahů toho vlastně nebylo moc, co by Bertík pro sebe mohl objevovat, jediné, co do textů prošlo, byl Bertíkův milovaný rybolov. V paměti mám tak spoustu Bertíkových textů, ve své podstatě všechny v šabloně: 1) šel jsem v sobotu na ryby; 2) chytil jsem kapra/lína/štiku/pstruha; 3 ) kapr/lín/štika/pstruh vážil a měřil tolik a tolik. 
A poté se Bertík pravidelně obhajoval, že rybu opravdu chytil a že nelže.

Domnívám se, že pro Bertíka by mohlo být autorské čtení velmi, velmi objevným polem možností k tomu, aby sám zjištoval, co se to s ním vlastně dělo a děje, jaké síly ho vưbec dynamizují a která témata jsou pro něj aktuální. Velkou pedagogickou otázkou pro mě zároveň jsou možnosti, které nabízí běžná realita školní výuky a síla zpětné vazby, kterou poskytují děti mladšího školního věku. Je možné, že kdyby dostal Bertík autentický prostor a skutečně by sám za sebe autorsky psal a četl, asi bychom se všichni divili - nejvíce asi já sám. Tolik odvahy jsem ale nikdy nesebral.

\section{Předběžné závěry}

Článek je součástí dlouhodobého zkoumání fenoménu tzv. experimentální dramatiky. Záměrem článku bylo narativním způsobem zformulovat dosavadní pedagogickou zkušenost s disciplínou autorské čtení v prostředí málotřídní školy. Pedagogická reflexe v celém článku je prozatímním materiálem pro formulování povahy takto vedené, teprve vznikající alternativní výuky, kombinuje teoretická východiska a data z výzkumu.

Výzkum je stále v procesu a vzniká na základě dlouhodobé přímé interakce v pedagogické realitě. Nevýhody tohoto typu zkoumání a limity výzkumu jsou v samotné povaze kvalitativního zkoumání. Závěry není možné zobecňovat a generalizovat.

Odpověd’ na hlavní a vedlejší výzkumnou otázku: zmiňované př́ípady dětských autorů textů ukazují, jak samotní aktéři k autorskému čtení přistupují. Při psaní tohoto článku se ukázalo, že formulovat zkušenosti s autorským čtením není možné bez přihlédnutí k osobnostním charakteristikám dětí a jejich konkrétních projevů. Ukázalo se, že do realizování autorského čtení $\mathrm{v}$ prostředí málotřídní školy svérázně intervenují i rodiče. Pedagogické zkušenosti z autorského čtení tedy nejdou studovat jako izolované jevy. Uvedené příklady také ilustrují, že autorské čtení nemusí být jediná (a zaručeně správná) cesta k rozvíjení vytyčených kompetencí. Na rozdíl od dospělých potřebují děti mladšího školního věku zpočátku určitou strukturu, např. zadání tématu. Ukazuje se dále, že téma, které je živé, provokativní a méně jednoznačné, vede k invenčním textům.

Ze získaných didaktických zkušeností je možné zmínit, že základem pedagogické práce s autorským čtením je postupné přenášení garance za tvưrčí proces na subjekt edukace (texty nejsou splněním vnějšího požadavku, ale radostnou možností k sebevyjádření žáků). Primárním cílem autorského čtení na 1. stupni se nesmí stát „hezký text“ jako konečný produkt určený k jednostrannému zhodnocení vyučujícím, ale společné objevování individuálních témat hodných ke zpracování, individuální ověřování osobitého autorského rukopisu bez „uměleckoidních“ naplavenin a rozvoj divergentního myšlení. Z pohledu pedagoga jde o sledování cesty spolu s žákem: „odkud-kam“ se žák v textech vyvíjí. Důraz je kladen na sdělné zveřejňování textu ostatním, tedy hlasité, civilní čtení s představou čteného.

Ze současného technologického pohledu na vzdělávání, ve kterém dominuje důraz na žákovský výkon a efektivitu, jde o protipól efektivního způsobu pedagogické práce. Problémem je metodická nejednoznačnost a nepostihnutelnost žádným $\mathrm{z}$ dostupných objektivních měřítek.

Kultivace autorství (tedy cesty k vlastnímu textu, k sebevyjádření) chce čas a především bezpečný prostor, jelikož starosti o předem daný výsledek určený k zhodnocení vše jaksi ztěžují. Pedagog garantuje vhodné podmínky pro tyto experimenty s autorskými texty: nehodnotící prostředí, respektování vývojových charakteristik žáků a individuálních zvláštností. Úlohou 
pedagoga je dále probouzet vzájemný respekt $\mathrm{k}$ textům a postupně kultivovat zpětnou vazbu tak, aby směřovala $\mathrm{k}$ věcnosti. $\mathrm{S}$ tím souvisí potřebná pedagogická trpělivost a takt.

\section{Kontakt}

\section{Mgr. Josef Nota, Ph.D.}

Jihočeská univerzita v Českých Budějovicích

Teologická fakulta

Katedra pedagogiky

Kněžská 8, 37001

jnota@tf.jcu.cz 